\title{
"Deiksis" dalam Kumpulan Cerpen Al-Kabuus Tinjauan Sosiopragmatik
}

\author{
Darsita
}

\begin{abstract}
Abstrak
Penelitian ini berupaya untuk menggambarkan pemakaian deiksis dalam teks terjemahan berbahasa Indonesia dari bahasa sumbernya, bahasa Arab. Deiksis dipahami sebagai bagian dari studi pragmatik, dengan begitu deiksis merupakan salah satu objek bidang kajian dari pragmatik. Masalah dalam penelitian ini: 1) bagaimanakah jenis-jenis deiksis; 2) bagaimanakan maksud dibalik penggunaan deiksis sosial pada kumpulan cerpen Al-Kabuus. Tujuan yang hendak dicapai dalam penelitian ini adalah: 1) untuk mendeskripsikan aneka jenis deiksis, 2) mendeskripsikan maksud penggunaan deiksis sosial pada kumpulan cerpen Al-Kabuus.

Objek penelitian yang dikaji adalah jenis, maksud serta hubungan deiksis sosial dengan yang terdapat pada cerpen Al-Kabuus. Subjek penelitiannya adalah cerpen karya Najib Kailani yang diterjemahkan oleh Zuriyati. Data dalam penelitian ini adalah kata, frase, klausa, kalimat yang di dalamnya terdapat jenis dan maksud penggunaan deiksis sosial dalam cerpen Al-Kabuus. Sumber data dalam penelitian ini terdiri dari sumber data primer dan sumber data sekunder.

Teknik pengumpulan data dalam penelitian ini dengan menggunakan dokumentasi. Hasil penelitian ini menunjukkan bahwa sebanyak 20 cerpen dari Al-Kabuus diperoleh 60 deiksis sosial, terdapat 5 deiksis sosial jenis gelar, 4 deiksis sosial jenis jabatan, 12 deiksis sosial jenis profesi, dan terdapat 36 deiksis sosial jenis julukan.
\end{abstract}

Kata Kunci: deiksis, deiksis sosial, al-kabuus, cerpen

\begin{abstract}
This study attempted to describe the use of deixis in Indonesian language translation text from the source language, Arabic. Deixis understood as part of a pragmatic study, so deixis is one of the object field of study of pragmatics. The problem in this research: 1) how the types of deixis; 2) how is the intention behind the use of social deixis on a collection of short stories Al-Kabuus. Goals to be achieved in this research are: 1) to describe the various types of deixis, 2) describe the intended use of social deixis on a collection of short stories Al-Kabuus.

The object of research by reviewing the type, purpose and relationship with the social deixis contained in Al-Kabuus short stories. Subject of research is the short story by Najib Kailani translated by Zuriyati. The data in this study are words, phrases, clauses, sentences in which there are different types and the intended use of social deixis in short stories Al-Kabuus. Sources of data in this study consisted of primary data sources and secondary data sources.

Data collection techniques in this study using documentation. The results of this study indicate that as many as 20 short stories from Al-Kabuus obtained 60 social deixis, social deixis there are 5 types of titles, positions four types of social deixis, social deixis 12 kinds of professions, and social deixis there are 36 kinds of nicknames.
\end{abstract} Keywords: deixis, social deixis, al-kabuus, short stories 


\section{Pendahuluan}

Karya sastra merupakan salah satu hasil cipta seni. Seni diyakini berumur setua peradaban manusia. Bagi umat Islam jalan pintas untuk memahami awal mula seni Islam dapat ditelusuri pada wahyu pertrama diturunkan, yaitu perintah membaca kepada Nabi Muhammad SAW. Kata iqra adalah verba imperatif yang berarti 'Bacalah!'. 'turunnya iqra adalah bunyi peluit dimulainya revolusi literasi yang dimomando Jibril untuk mencerdaskan manusia. Membaca mengandung serentang makna kognitif, afektif, dan motorik seperti mengetahui, meneliti, mengamati, merenungkan dan merasakan. Kata Iqra merupakan verba transitif dalam surat Al-Alaq tidak diikuti oleh objek. Ini ditafsirkan bahwa membaca di sini tidak terbatas hanya pada tulisan, tetapi merujuk pada objek yang lebih umum termasuk alam semesta. $^{2}$

Mengamalkan perintah yang tertera di dalam Al-Quran seperti tertera di atas adalah membaca sebuah karya sastra, yang berupa cerpen terjemahan dari satu bahasa ke bahasa lain merupakan kegiatan yang sangat menyenangkan, pendapat ini disampaikan atas dasar pengalaman yang bersifat pribadi. Karya sastra yang diambil sebagai objek kajian ini adalah karya sastra berupa cerpen yang diterjemahkan dari bahasa Arab ke dalam bahasa Indonesian oleh Zuriyati (2005). Karya sastra itu berupa kumpulan cerpen yang berjudul "AlKabuus" yang ditulis oleh Najib Kailani seorang sastrawan yang lahir pada tahun 1931 di kota Sarsabah, Mesir. Di dalam

\footnotetext{
${ }^{1}$ A. Chaedar Alwasilah. Filsafat Bahasa dan Pendidikan. (Bandung: Remaja Rosdakarya, 2010)., hal 207-208

${ }^{2}$ Ibid.
}

karya ini banyak dikisahkan berbagai aspek kehidupan manusia, khususnya yang mengandung nilai-nilai asal kebudayaan Arab, khususnya di Mesir, yang meliputi nama-nama orang seperti Fuad, Muhammad, Salim, Laila, Najyah, Abdullah, Abdul Aziz, Said, Bakri, Alhajah Khadrah, tentang budi pekerti, kehidupan keluarga, perbudakan, aib, keadaan alam, kehidupan beragama, ekonomi, sosial, pendidikan dan lain sebagainya.

Karya sastra berupa cerpen dalam telaah ini dianggap sama dengan sebuah cipta sastra. Karya sastra cerpen diasumsikan merupakan gambaran kehidupan berdasarkan kenyataan sosial. Fakta dalam cerita pendek hasil terjemahan dari bahasa Arab ke bahasa Indonesia itu menggambarkan masalah manusia dalam kehidupannya. Dalam kisahan cerpen ini pengarang mengungkapan gagasan tentang kehidupan bangsa Arab di Mesir yang diolah melalui perenungan penghayatan dan imajinasinya yang dituangkan dalam teks berbahasa Arab untuk dinikmati oleh para pembaca. Pertanyaan yang dapat diajukan Apa yang dimaksud karya sastra? Karya sastera menurut pendapat Teeuw (1997) adalah pengarang selalu hadir dalam karya yang diciptakannya dengan seluruh kemanusiaanya, suka dan dukanya, impiannya, sukses, kegagalan, dengan perlawanan dan penyerahannya pada situasi hidup. ${ }^{3}$

Pembaca yang membaca sebuah karya sastra terjemahan dari bahasa Arab ke dalam bahasa Indonesia, akan mengalami kontak budaya. Kontak budaya itu terjadi karena pembaca melakukan pengenalan, pemahaman terhadap karya sastra yang dibacanya itu, sehingga ia dapat melakukan penilaian, dan muncul kegairahan serta

\footnotetext{
3 A.Teeuw. Citra Manusia dalam Karya Sastra. (Jakarta: Gramedia, 1997 ) ., hal 2
} 
kenikmatan yang timbul sebagai akibat dari membaca karya itu. Mengapa pembaca dapat ikut larut dengan keadaan yang disajikan dalam sebuah karya sastra itu? Shipley (1962) dalam Rusyana (1979) menjelaskan bahwa pembaca yang dapat memetik nilai kehidupan yang terkandung dalam sebuah karya sastra karena ada daya empati yang memungkinkan pembaca terbawa ke dalam suasana dan gerak hati, dalam karya itu. ${ }^{4}$ Lebih lanjut, Rusyana (1979) mengemukakan bahwa kemampuan mengalami pengalaman pengarang yang tertuang dalam karyanya dapat menimbulkan rasa nikmat pada pembaca. Kenikmatan itu timbul karena pembaca, merasakan beberapa situasi berikut: 1) berhasil dalam menerima pengalaman orang lain; 2) bertambah pengalaman sehingga dapat menjalankan kehidupan dengan lebih baik; 3) kagum akan kemampuan sastrawan yang mengerahkan segala alat yang ada padea medium seninya sehingga ia memperjelas, memadukan dan memberikan makna terhadap pengalamann yang diolahnya, dan 4) menikmati sesuatu demi sesuatu itu sendiri, yaitu kenikmatan estetik. ${ }^{5}$

Pembaca yang demikian itu, menurut Rusyana (1979) adalah pembaca yang melakukan apresiasi sastra. Selanjutnya, dijelaskan bahwa apresiasi sastra memiliki beberapa tingkatan, yaitu:

1) Tingkat pertama, apresiasi sastra terjadi apabila seseorang mengalami pengalaman yang ada dalam sebuah karya. Pembaca itu

${ }^{4}$ Rusyana, Rus. "Meningkatkan Kegiatan Apresiasi Sastra di Sekolah Lanjutan" dalam Jurnal Pengajaran Bahasa dan Sastra Tahun 4 Nomor 1. (Jakarta: Pusat Pembinaan dan Pengembangan Bahasa Departemen Pendidikan dan Kebudayaan, 1979)., hal 23.

${ }^{5}$ Ibid., Rusyana (1979)., hal 24 terlibat secara intelektual, emosional, imajinatif dengan karya itu;

2) Tingkat ke dua apresiasi sastra terjadi apabila daya intelektual pembaca bekerja lebih giat. Pembaca mulai bertanya kepada dirinya tentang makna pengalaman yang diperolehnya, tentang pesan yang disampaikan pengarang, tentang hal yang tersembunyi di belakang alur, dan lain-lain.

3) Tingkat ke tiga apresiasi terjadi apabila pembaca menyadari pula hubungan karya sastra itu dengan dunia di luarnya sehingga pemahaman dan penikmatannya pun dapat dilakukan dengan lebih luas dan mendalam. ${ }^{6}$

Apresiasi sastra memiliki relasi erat dengan kegiatan apresiasi. Frase kegiatan apresiasi untuk penjelasannya, terlebih dahulu dijelaskan kata kegiatan, kemudian gabungan kata kegiatan apresiasi. Makna masing-masing satuan lingual itu secara leskikal dijelaskan satu persatu. Merujuk konsepsi Rusyana (1979) yang menjelaskan bahwa kegiatan adalah perbuatan yang dilakukan dengan sadar dan bertujuan, yaitu perbuatan yang direncanakan berdasarkan asas-asas untuk mencapai sasaran yang ditentukan, untuk memenuhi baik kebutuhan jasmani maupun kebutuhan sosial budaya. Kegiatan apresiasi adalah perbuatan yang dilakukan dengan sadar dan bertujuan untuk mengenal dan memahami dengan tepat nilai sastra, untuk menumbuhkan kegairahan kepadanya dan memperoleh kenikmatan daripadanya.

Bertumpu dari pendapat ini dipahami bahwa karya sastra Arab menggambarkan manusia dalam kehidupannya dan dunia sastra adalah

${ }^{6}$ Ibid. 
dunia yang menarik karena sastra tidak hanya menggambarkan imajinasi kreatif yang dikembangkan pengarangnya tapi juga merupakan gambaran situasi sosial bangsa Arab Mesir yang sebenarnya. Berangkat dari pendapat ini cerita pendek terjemahan Arab-Indoensia dianggap sebagai sebuah dunia yang menarik, unik, dan spesifik, karena cerita pendek itu menyajikan imajinasi kreatif yang disuguhkan oleh pengarang kepada pembacanya, jadi cerpen dapat dianggap sebagai sebuah dokumen sosial. Salah satu produk cerita pendek berasal dari Arab yang berjudul "Halusinasi" merupakan karya yang ditampilkan, digagas, dibuat oleh pengarang Arab di Mesir. Sebuah karya sastra entah cerita pendek, entah novel, atau drama dapat memperlihatkan kekhasan, keunikan yang berkaitan dengan kultur etnik suatu suku bangsa, bangsa yang sekian lama mengeram, mendekam, dan mengalir menjadi pola pikir, prilaku, dan sikap hidup, tatakrama dan etika, tindakan dan ekspresi diri pandangan dan orientasi tentang alam dan lingkungannya, bahkan juga sampai pada wawasan estetiknya. ${ }^{7}$

Seluk beluk kehidupan orang Arab di Mesir seperti konflik kehidupan berumah tangga, kesenjangan sosial, kegelisahan batin orang-orang tertindas, harapan, kekecewaan, keadilan, kekejaman, kemiskinan, kekayaan yang berlimpah ruah, perkuliahan, percintaan, pelecehan seksual, menjadi tema yang sering ditampilkan dalam karya-karya sastra Arab sejak dulu hingga sekarang contohnya cerpen "Orang Asing" (2005), "Otoriter" (2005), "Aib" (2005), "Hati Perempuan (2005)"; adalah cerita pendek yang disaru oleh Zuriyati (2005) dari buku Al-Kabuus karya Najib Jailani.

\footnotetext{
${ }^{7}$ Maman S.Mahayana.. Esktrinsikalitas Sastra Indonesia (Jakarta : Raja Grafindo Perasada. 2007).,

hal 4
}

Selanjutnya, "Perempuan yang mengalahkan Setan" (2008), "Di Tahun Sejuta Masehi" (2008), "Perempuan itu Sungguh Misteirus" (2008) adalah naskah kumpulan cerita pendek berbahasa Arab Arinillah karya Taufiq El Hakim yang diterjemahkan ke dalam bahasa Indonesia oleh Arif Sirsaeba (2008). Berdasarkan karya-karya karya terjemahan itu, pada kesempatan ini dipilih satu cerpen berjudul "Hati Perempuan". Cerita pendek tersebut diambil dari kumpulan cerpen yang berjudul Al-Kabuus karya Najib Jailani. Karya itu dapat diperoleh dari hasil terjemahan. Berkat adanya kegiatan penerjemahan deari bahasa Arab ke dalam bahasa Indonesia yang berkembang saat ini, hal itu memudahkan setiap orang untuk dapat membaca karya itu yang layak untuk dibaca. Karya sastra itu pada umumnya menyampaikan pesan-pesan berupa pendidikan, nilai, moral, etika, persoalan ekonomi, sosial, politik dan pentingnya seorang istri taat kepada suami demikian pula sebaliknya. Karya sastra cerpen "Hati Perempuan", yang dibaca kemudian dipikirkan lalu diputuskan oleh penulis untuk dijadikan objek bahasan dalam kajian ini.

Masalah yang dibahas, antara lain berupa: a) jenis-jenis deiksis; b) maksud dibalik pemakaian deiksis dalam karya terjemahan berbahasa Indonesia.

Penelitian ini memiliki tiga tujuan yaitu :

1. Mengetahui berbagai jenis deiksis dalam karya terjemahan Arab Indonesia yang berjudul "Hati Perempuan" meliputi yaitu : a) deiksis persona ; b) deiksis tempat ; c) deiksis wacana ; d) deiksis sosial meliputi gestural, dan simbolik.

2. Mencari tahu maksud dibalik pemakaian deiksis dalam karya cerita pendek itu. 
Masalah yang diangkat dalam kajian ini berfokus pada hal-hal itu sebagai berikut

1. Bagaimana bentuk-bentuk deiksis dalam Cerpen karya Najib Kailani terjemahan Arab Indonesia yang berjudul "Al-Kabuus" meliputi yaitu : a) deiksis persona ; b) deiksis tempat ; c) deiksis wacana ; d) deiksis sosial

2. Bagaimana pamakaian deiksis dalam kalimat imperatif bahasa Indonesia karya cerita pendek itu.

Penelitian ini hasilnya akan bermanfaat baik secara teoretis maupun secara praktis uraiannya sebagai berikut : 1 . Manfaat teoretis. Penelitian ini memberi dua manfaat teoretis yaitu: 1) Memahami pemakaian deiksis dalam karya terjemahan bahasa Arab ke dalam bahasa Indonesia; 2) Memahami kerangka teori pragmatik yang terdapat dalam karya terjemahan itu . 2. Manfaat praktis. Penelitian ini memberi dua manfaat praktis yaitu : 1) Sebagai bahan pertimbangan bagi praktek penerjemahan bahasa Arab ke dalam bahasa Indonesia dalam menyusun dalam perencanaan pemakaian bahasa Indonesia; 2) Hasil penelitian ini bermanfaat untuk mengetahui jenis-jenis deiksis bahasa Indonesia

Objek penelitian ini diarahkan pada deiksis yang terdapat dalam teks hasil terjemahan dari bahasa Arab ke dalam bahasa Indonesia yang terdapat di dalam kumpula cerpen berjudul "Halusisnasi" karya Zuriyati. Analisis menyangkut deiksis tersebut dilakukan melalui distribusi deiksis di dalam kalimat dan konteks penggunaan deiksis itu dalam setiap peristiwa tutur. Analisis dibatasi pada analisis deiksis persona, waktu, tempat, deiksis wacdana, sosial termasuk gestural dan simbolik, khususnya untuk mengetahui distribusi deiksis itu dan analisis wacana deiksis untuk mengetahui wujud-wujud ungkapan pragmatik serta maknamaknanya dan keterlibatan konteksnya.

Metode yang digunakan dalam penelitian ini adalah metode dekriptif. Metode deskriptif adalah metode yang dilakukan semata-mata hanya berdasarkan pada fakta yang ada atau fenomena yang memang secara empiris hidup pada penutur-penuturnya sehingga yang dihasilkan adalah paparan seperti apa adanya. ${ }^{8}$ Penelitian ini membedakan istilah metode dan teknik sebagaimana disarankan oleh Sudaryanto (1988). Istilah teknik tidak dipakai dalam hubungan sinomimi dengan istilah metode, melainkan dipakai dalam hubungan hiponimi. Konsep teknik diturunkan dari konsep metode. Atas dasar konsepsi itu penelitian ini dilakukan dengan tahap-tahap sebagai berikut:

\section{Pengumpulan Data}

Kalimat di dalam teks yang menjadi data penelitian ini dikumpulkan melalui pengamatan langsung, yaitu dengan cara membaca, data yang diamati itu kemudian dicatat. Penelitian ini menggunakan konsepsi Sudaryanto (1988) menjelaskan metode yang dapat digunakan untuk pengumpulan data lingual berupa teks. Penyimakan atau metode simak atau penyimakan, adalah metode menyimak penggunaan bahasa pada sebuah teks. Metode simak dapat dijabarkan dalam sebuah wujud teknik sesuai macam alatnya, yaitu teknik catat. $^{9}$

\footnotetext{
Sudaryanto. Metode Linguistik: Ke Arah Memahami Metode Linguistik. (Yogyakarta: Gadjah Mada Univeresity Press, 1992)., hal 62.

${ }^{9}$ Ibid., Sudaryanto., hal 2
} 


\section{Metode}

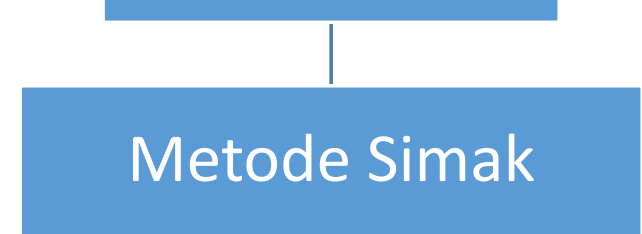

Teknik Catat

Bagan 1 Hierarki Metode Penelitian ini

Bagan 1 di atas dapat dijelaskan sebagai berikut:

Konsepsi metode dalam penelitian ini berposisi sebagai hiponimi dari konsep teknik. Metode yang digunakan dalam penelitian ini ada dua jenis, yaitu:

Metode simak yaitu metode pemerolehan data yang dilakukan peneliti dengan cara melakukan penyimakan penggunaan bahasa di dalam teks terjemahan yang digunakan yang digunakan penerjemah bahasa untuk menggambarkan setiap peristiwa tutur. Metode ini memiliki teknik dasar berupa teknik catat. Dikatakan teknik catat karena penyimakan dilakukan dengan pencataan. Pencatatan dapat dilakukan secara tersistmatisasi dari setiap topik pembicaraan. Pencatatan dilakukan secara bertahap agar data yang diperoleh bersifat teratur sehingga dapat diamati penggunaan bahasanya. Bertumpu kepada metode ini, alat tulis yang digunakan peneliti berupa alat ketik seperti laptob. Alat tulis berupa pulpen, pensil, dan stabilo warna warni digunakan untuk menandai data yang diperlukan dari naskah terjemahan itu. Alasan penggunaan metode ini adalah untuk mendapatkan keaslian dari bahasa yang digunakan dan hasil pengamatan secara cermat.

\section{Pengolahan Data}

Data berupa hasil pencatatan yang telah dihimpun dikelola dengan tahapan-tahapan sebagai berikut:

1) Hasil catatan terlebih dahulu dimasukkan ke dalam komputer/labtop;

2) Hasil catatan dibaca berulang-ulang;

3) Data yang mengandung deiksis yang dijadikan korpus untuk selanjutnya dianalisis.

\section{Analisis Data}

Data yang sudah diperoleh dianalisis menggunakan:

1) tabel-tabel yang disarankan oleh Rahardi (2011). Setiap tabel analisis berisi: nomor data, lokasi percakapan, konteks tuturan, wujud deiksis, jenis kalimat dan makna imperatif. ${ }^{10}$

2) Untuk mencari tahu berbagai deiksis dilakukan dengan menganalisis deiksis itu sesuai dengan distribusinya.

Sumber data yang digunakan adalah:

1) Data penelitian deiksis mencakupi semua tuturan dalam teks terjemahan;

2) Identitas sebuah deiksis sebagai objek sasaran apabila deiksis itu muncul bersama dengan respons atau tanggapannya. Alasannya, tanggapan dapat berupa ungkapan yang di dalamnya

\footnotetext{
${ }^{10}$ Op.cit., Rahadi Kundjana, 2011., hal 51
} 
da kandungan gestural atau simbol.

3) Data diambil pada kurun waktu 1November31Desember 2015

\section{Tinjauan Pustaka dan Kerangka Teoretis}

\section{A.Tinjauan Pustaka}

Kaswanti (1984) dalam penelitiannya yang berjudul Deiksis dalam Bahasa Indoensia, membedakan deiksis menjadi: deiksis luar tuturan atau eksofora dan deiksis dalam tuturan atau endofora. Yang membedakan labuhan "setting anchorage" luar tuturan dengan labuhan dalam tuturan adalah bidang permasalahannya. Yang dipermasalahkan dalam pembahasan tentang eksofora adalah bidang semantik leksikal, meskipun bidang sintaksis tidak dapat dilepaskan sama sekali dari pembahasan bidang semantik leksikal. ${ }^{11}$

Mey (1993) mengemukakan kata deiksi berasal dari kata Yunani deiktitos yang berarti 'hal penunjukkan secara langsung. Sebuah kata dikatakan bersifat deiktis apabila referennya berpindahpindah atau berganti-ganti tergantung pada saat dan tempat dituturkannya kata itu. $^{12}$ Mey menjelaskan bahwa seorang penutur yang berbicara dengan lawan tuturnya seringkali menggunakan katakata yang menunjuk baik pada orang, waktu maupun tempat. Kata-kata yang lazim disebut dengan deiksis tersebut berfungsi menunjukkan sesuatu, sehingga keberhasilan suatu interaksi antara penutur dan lawan tutur sedikit banyak akan bergantung pada pemahaman deiksis yang dipergunakan

11 Bambang Kaswanti Purwo. Deiksis dalam Bahasa Indonesia (Jakarta: Balai Pustaka, 1984)., hal 19

12 Jacob L Mey. Pragmatics An Introduction. (Cambridge: Cambridge University Press)., 8998pp oleh seorang penutur. Mey (1993: 89) dalam Nadar (2009) memberikan contoh seorang tamu hotel di negara asing yang sedang berada di kamarnya. Tiba-tiba ada ketukan di pintu kamarnya, dan dia bertanya "Who is there?", serta dijawab dengan "It's me". Bagi tamu hotel tersebut, kata me tidak memperjelas siapa penuturnya, karena me menunjuk pada seseorang yang bagi tamu tersebut juga tidak jelas. Dengan demikian me adalah kata deiksis, yang menunjukkan pada diri orang yang mengucapkannya. Kalau orangnya berubah, maka me menunjuk pada orang yang berbeda pula. Mengingat kekhususan penggunaan me, sebagaimana dalam konteks percakapan antara tamu hotel dengan orang yang mengetuk pintu tersebut.

\section{B. Kerangka Teoretis}

Deiksis menurut Purwo (1990) merupakan salah satu aspek pragmatik di antara tiga aspek lainnya yaitu (i) praanggapan (presuppsition), (ii) tindak ujaran (speech act), dan (iii) implikatur percakapan (conversational implicature $){ }^{13}$ Dijelaskan lebih lanjut kata seperti, saya sini, sekarang adalah kata-kata deiksis. Kata-kata ini tidak memiliki referen yang tetap. Berbeda halnya dengan kata kursi, rumah, kertas. Siapapun yang mengucapkan kata kursi, rumah, kertas di tempat mana pun, pada waktu kapan pun, referen yang diacu tetaplah sama. Akan tetapi referen dari kata saya, sini, sekarang barulah dapat diketahui jika diketahui pula siapa, di tempat mana, dan padea waktu kapan kata-kata itu diucapkan. Konsep deiksis selanjutnya dapat disimak dari Lyons (1977). Dijelaskan oleh beliau bahwa deiksis dipakai untuk menggambarkan

\footnotetext{
13 Bambang Kaswanti Purwo. Pragmatik dan Pengajaran Bahasa Menyibak Kurikulum 1984. (Yojyakarta: Kanisius, 1990)., hal 17
} 
beberapa fungsi: 1) pronomina persona, 2) demostrativa, 3) fungsi waktu, 4) aneka ciri gramatikal, serta 5) leksikal lainnya yang menghubungkan ujaran dengan jalinan ruang dan waktu dalam tindak ujaran. ${ }^{14}$ Sedangkan, menurut Levinson (1983) mengemukakan bahwa deiksis dibedakan atas lima macam yakni deiksis persona, deiksis waktu, deiksis tempat, deiksis wacana dan deiksis sosial. ${ }^{15}$ Uraiannya sebagai berikut:

1) Deikis Persona adalah menunjuk peran dari partisipan dalam peristiwa bahasa saat ujaran tersebut diucapkan. Deiksis orang terdiri dari kategori orang pertama, orang kedua, dan orang ketiga. Konsepsi ini kemudian digunakan sebagai landasan berpikir untuk memetakan pronominal dalam bahasa Indonesia yang dipakai untuk memahami pronominal dalam objek kajian ini. Uraiannya sebagai berikut:

Deiksis orang pertama yaitu kata yang menggantikan diri orang yang berbicara.

Deiksis orang kedua yaitu kata yang menggantikan diri orang yang diajak bicara.

Deiksis orang ketiga yaitu kata yang menggantikan diri orang yang dibicarakan

2) Deiksis Tempat

Deiksis tempat merujuk kepadea pemberian bentuk pada tempat menurut peserta dalam peristiwa bahasa. Deiksis tempat digunakan untuk mengacu kepada tempat terjadinya suatu peristiwa tutur, baik tempat dekat (proksimal), agak jauh (semi- proksimal), maupun tempat yang jauh (distal).

3) Deiksis Waktu

\footnotetext{
${ }^{14}$ Lyons, John. Semantics (Cambridge: Cambridge University Press, 1977)., p. 636

15 Steven C. Levinson. Pragmatics. (Cambridge: Cambridge Univeersity Press, 1983)., hal 64.
}

Deiksis waktu merujuk kepada pemberian bentuk pada rentang waktu saat ujaran dituturkan. Deiksis ini merujuk kepada waktu berlangsungnya sebuah peristiwa, baik kala lampau, kala kini, maupun kala mendatang.

\section{Deikis Wacana}

Untuk memahami deiksis wacana, pertama dikemukakan pengertian wacana. Wacana adalah: 1) rentetan kalimat yang berkaitan, yang menghubungkan proposisi yang satu dengan proposisi yang lainnya, membentuk satu kesatuan sehingga terbentuklah makna yang serasi di antara kaimat-kalimat itu; 2) kesatuan bahasa yang terlengkap dan tertinggi atau terbesar di atas kalimat atau klausa dengan koherensi dan kohesi yang tinggi dan berkesinambungan, yang mempunyai awal dan akhir yang nyata, dan disampaikan secara lisan dan tertulis. $^{16}$ Konsepsi Deiksis wacana merujuk kepada bagian-bagian tertentu dalam wacana yang telah diberikan atau sedang dikembangkan. Deiksis wacana berkaitan dengan penggunaan ungkapan dalam suatu ujaran untuk mengacu pada bagian dari ujaran yang mengandung ungkapan.

\section{Deiksis Sosial}

Deiksis sosial ialah pemberian bentuk menurut perbedaan sosial yang mengacu pada peran peserta, khususnya aspek-aspek hubungan sosial antara pembicara dan pendengar atau pembicara dengan beberapa rujukan. Deiksis ini bertemali erat berkaitan dengan para partisipan (penyapa, pesapa, acuan), karena itu dalam deiksis terlibat

\footnotetext{
${ }^{16}$ J.S Badudu (2000) dalam I Dewa Putu Wujaya dan Muhammad Rohmadi. Analisis Wacana Pragmatik Kajian Teori dan Analisis (Surakarta: Yuma Pustaka, 2011)., hal 69
} 
unsur honorik atau sebutan penghormatan dan etika bahasa. ${ }^{17}$

3. Penggunaan Ekspresi Deiksis

Levinson (1983) mengemukakan bahwa penggunaan ekspresi deiksis ini dapat dibagi menjadi dua hal yaitu penggunaan gestural dan simbolik. Uraian secara konseptual sebagai berikut:

1) Gerak Fisik (gestural)

Penggunaan deiksis secara gestural merujuk pada penggunaan ekspresi deiksis yang memerlukan informasi indikasi gerakan atau audio visual yang dapat memahami penggunaan ekspresi deiksis tersebut. Untuk memahami makna dari penggunaan suatu rujukan, penggunaan ekspresi deiksis tersebut dibutuhkan pengamatan atau pemantauan aspek indikasi fisikal dalam suatu konteks ujaran. Indikasi yang bersifat fisik ini dapat berupa gerakan tubuh seperti pandangan mata, gerakan tangan, atau ekspresi wajah dari partisipan. Penggunaan gestural berfungsi untuk mengarah perhatian dari lawan bicara dengan memberikan gerakan visual untuk menunjuk kepada rujukan sehingga dapat membantu memahami ke mana rujukan itu ditujukan.

2) Simbolik (symbolic)

Penggunaan deiksis simbolik yaitu penggunaan yang penafsirannya dilakukan dengan menganalisis aspek situasi yang terdapat dalam suatu konteks ujaran. Ujaran tersebut untuk memahami maksud rujukan. Ekspresi simbolik tersebut dilakukan dengan faktor tempat, waktu, ataupun melihat rujukan lawan bicara. Untuk memahami rujukan atau ungkapan dapat dipahami tanpa gerakan fisik dan rujukannya dapat diketahui hanya dari tuturannya,

17 Charles J. Fillmore. Santa Cruz Lectures on Deixis 1971. (Bloomington: Indiana University Linguistics Club)., 76p melainkan hanya dengan mengetahui faktor atau konteks yang menyertai ungkapan tersebut. 


$\begin{array}{lrl}\text { Selanjutnya, Kaswanti Purwo } & \text { deiksis persona, ruang, waktu. Contoh- } \\ \text { (1984) menyusun diagram yang } & \text { contoh berikut diambil dari diagram } \\ \text { menjelaskan secara rinci contoh-contoh } & \text { tersebut: }\end{array}$

Deiksis Persona

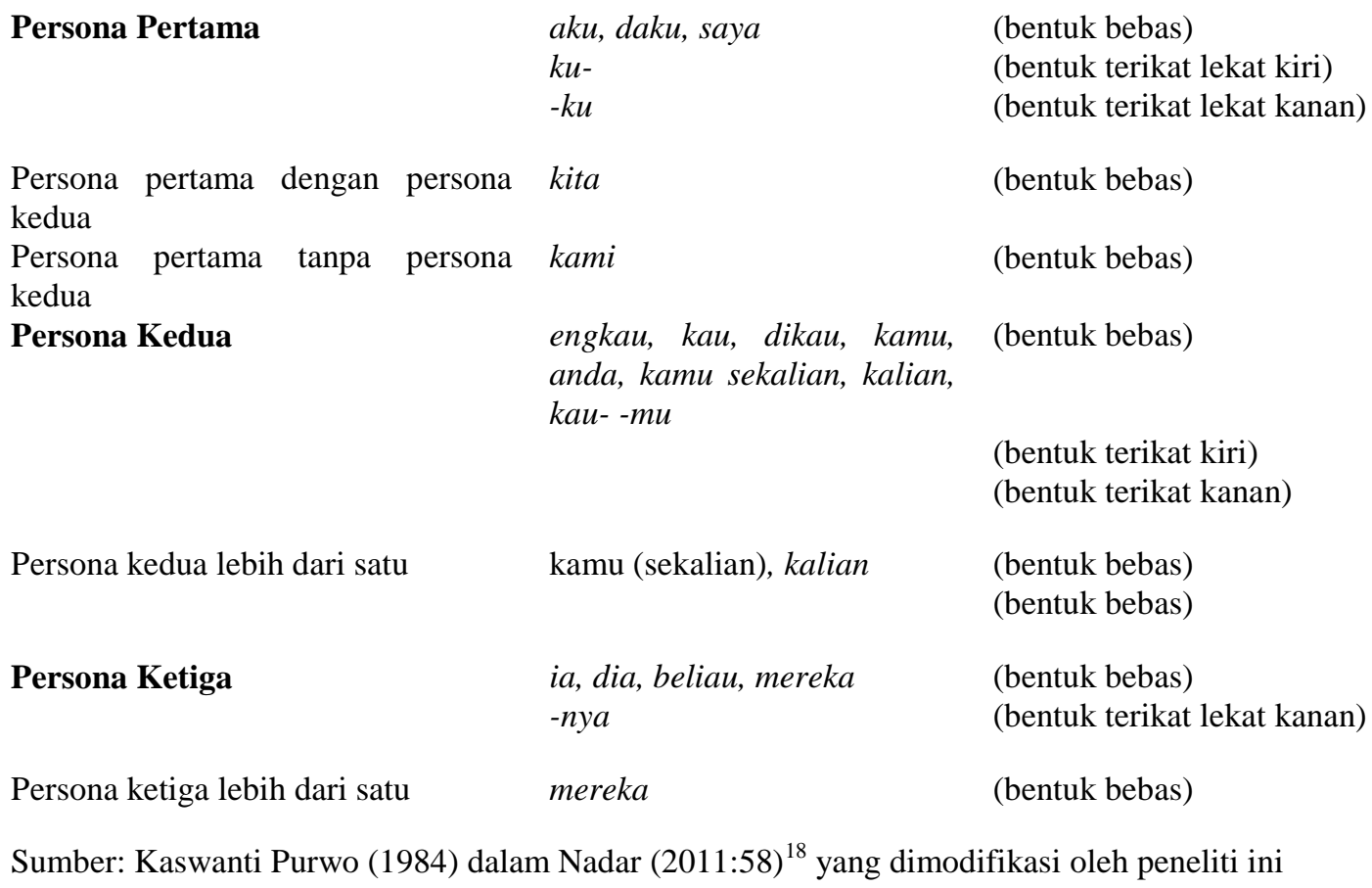

Deiksis ruang

Lokatif sini,situ, sana

Demonstratif $\quad$ ini, itu, begini, begiut

Temporal kini, dini

Sumber: Kaswanti Purwo (1984) dalam Nadar (2011:58) ${ }^{19}$ yang dimodifikasi oleh peneliti ini

\section{Deiksis Waktu}

\footnotetext{
${ }^{18}$ Abdul Chaer. Tata Bahasa Praktis Bahasa Indonesia. (Jakarta: Rineka Cipta, 2000)., hal 91-98 ${ }^{19}$ Ibid.
} 
Darsita : "Deiksis" dalam ... 353

$\begin{array}{lll}\text { Waktu yang telah lalu } & \text { Waktu sekarang } & \text { Waktu yang akan datang } \\ \text { minggu (yang) lalu } & \text { minggu ini } & \text { besuk, (hari) lusa, besuk lusa } \\ \text { (hari) Kamis (yang) lalu } & \text { hari Kamis ini } & \text { nanti, kelak } \\ \text { bulan (yang) lalu } & \text { bulan ini } & \text { bulan depan } \\ \text { (bulan) April (yang) lalu } & \text { bulan April ini } & \text { minggu yang akan datang } \\ \text { tahun (yang lalu) } & \text { tahun ini } & \\ \text { (tahun) 1951 yang lalu } & \text { (tahun) } 1983 \text { ini } & \\ \text { kemarin dulu, kemarin } & \text { sekarang } & \\ \text { tadi } & \end{array}$

Sumber: Kaswanti Purwo (1984) dalam Nadar (2011:58) ${ }^{20}$ yang dimodifikasi oleh peneliti ini.

${ }^{20}$ Ibid. 
Dalam endofora dibahasa antara lain masalah pemarkah anaphora (mengacu padea konstituen di sebelah kirinya) dan dan katafora (mengacu pada konstituen di sebelah kanannya) baik yang persona maupun bukan perosna, dan juga pemarkah anaphora dan katafora yang berupa konstituen Nol. ${ }^{21}$ Mengenai pemarkah anaphora dan katafora ditegaskan bahwa hanya kata ganti persona ketiga yang dapat menjadi pemarkah anaphora dan katafora. Contoh pemarkah anaphora dapat dilihat pada penggunaan kata "ia" dan "dia". Kerangka teorietis di atas digunakan untuk menganalisis data deiksis yang terdapat dalam cerpen ini.

\section{Analisis dan Pembahasan}

\section{Analisis}

Seperti yang telah dijelaskan pada bagian sebelumnya, penelitiann yang penulis lakukan adalah mengenai deiksis persona, deiksis ruang, deiksis waktu, deiksis wacana, deiksis sosial. Data yang penulis peroleh, didapat dari buku kumpulan cerpen yang berjudul Al-Kabuus yang diterjemahkan 'halusinasi' oleh Zuriyati (2005). Pembagian deiksis dalam penelitian ini menggunakan konsep kategori Kaswanti Purwo (1984) dalam bahasa Indonesia yang ditulis oleh Kaswanti Purwo (1984).

1) $\begin{aligned} & \text { Deiksis Persona } \\ & \text { Tunggal }\end{aligned}$
$\begin{aligned} & \text { Deiksis persona } \\ & \text { berhubungan }\end{aligned}$
pertama
dunggal dengan
pemahaman mengenai peserta tuturan
dalam situasi pertuturan di mana tuturan
itu dibuat. Berikut contoh penggunaan
deiksis persona.

${ }^{21}$ Op.cit. hal 103-105
1) Dalam kumpulan cerpen data berupa deiksis diambil dari setiap kisahan. Buku kumpulan cerpen ini memuat 17 buah cerpen. Untuk mencari data deiksis persona diambil secara acak menggunakan tabel-tabel dengan alasan untuk memudahkan analisis. Analisis deiksis persona itu sebagai berikut. 
Tabel 1

Analisis Deiksis Persona Pertama

\begin{tabular}{|c|c|c|c|c|c|}
\hline No & Lokasi terjadinya tuturan & Wujud Imperatif & Konteks tuturan & Makna imperatif & $\begin{array}{l}\text { Deikis } \\
\text { persona }\end{array}$ \\
\hline h. 21 & Dialog di dalam rumah & $\begin{array}{l}\text { "Hasil } \\
\text { pemeriksaan } \\
\text { dokter } \\
\text { menyalahkan } \\
\text { aku". }\end{array}$ & $\begin{array}{l}\text { Mereka punya harta } \\
\text { berlimpah.. } \\
\text { dengan sekejap mata } \\
\text { tragedi datang } \\
\text { merenggut } \\
\text { kebahagiaan mereka } \\
\text { karena ada satu yang } \\
\text { mereka tidak miliki } \\
\text { yaitu anak }\end{array}$ & pernyataan & 'aku' \\
\hline h. 42 & & $\begin{array}{l}\text { "Aku tidak mau } \\
\text { dikatakan seorang } \\
\text { laki-laki lemah. } \\
\text { Selama ini aku } \\
\text { mampu } \\
\text { mendapatkan apa } \\
\text { saja yang aku } \\
\text { inginkan }\end{array}$ & $\begin{array}{lr}\text { Setelah } & \text { mengetahui } \\
\text { hasil } & \text { pemeriksaan } \\
\text { dokter } & \end{array}$ & pernyataan & 'aku’ \\
\hline h. 31 & $\begin{array}{l}\text { Di ruang makan di dalam } \\
\text { rumah }\end{array}$ & $\begin{array}{l}\text { "Aku harus punya } \\
\text { punya, anak, } \\
\text { harus". }\end{array}$ & $\begin{array}{lr}\text { Tokoh } r & \text { Salim } \\
\text { menyangkal hasil } & \text { hemeriksaan dokter }\end{array}$ & harapan & 'aku' \\
\hline h. 49 & $\begin{array}{l}\text { Di ruang keluarga di dalam } \\
\text { rumah }\end{array}$ & $\begin{array}{l}\text { "Aku bisa gila, di } \\
\text { mana keadilan? }\end{array}$ & $\begin{array}{l}\text { Tokoh Salim iri } \\
\text { dengan } \\
\text { tetangganya yang bisa } \\
\text { hamil, sedang istrinya } \\
\text { tidak bisa hamil }\end{array}$ & pertanyaan & 'aku' \\
\hline h.53 & $\begin{array}{l}\text { Di ruang praktek dokter } \\
\text { kandungan untuk kunjungan } \\
\text { pertama }\end{array}$ & $\begin{array}{l}\text { "Saya pastikan } \\
\text { Anda sehat dan } \\
\text { tidak mandul. }\end{array}$ & $\begin{array}{ll}\text { Laila memeriksakan } \\
\text { kandungannya } & \text { ke } \\
\text { dokter kandungan } & \end{array}$ & pernyataan & 'saya' \\
\hline h.56 & $\begin{array}{l}\text { Di ruang praktek dokter } \\
\text { kandungan untuk kunjungan } \\
\text { ke-2 }\end{array}$ & $\begin{array}{l}\text { "Saya ingin } \\
\text { bertanya } \\
\text { sejujurnya. } \\
\text { Mengapa kau } \\
\text { harus berbuat } \\
\text { zalim...?" }\end{array}$ & \begin{tabular}{lr}
\multicolumn{2}{l}{ Laila memeriksakan } \\
kandungannya & ke \\
dokter kandungan &
\end{tabular} & pertanyaan & 'saya' \\
\hline h.71 & $\begin{array}{l}\text { Di ruang tidur di dalam } \\
\text { rumah }\end{array}$ & $\begin{array}{lr}\text { "Kau } & \text { bagiku } \\
\text { adalah } & \text { suami, } \\
\text { saudara } & \text { dan } \\
\text { anak" } & \end{array}$ & $\begin{array}{l}\text { Setelah mendapat } \\
\text { penjelasan dari dokter } \\
\text { kandungan bahwa } \\
\text { Salim mandul }\end{array}$ & pernyataan & '-ku’ \\
\hline
\end{tabular}

Analisis data seperti tertera pada tabel 1 menunjukkan bahwa, penggunaan deiksis persona pertama pada umumnya menggunakan $a k u$, saya, dan $-k u$ bentuk terikat lekat kanan. $A k u$, dan $-k u$ digunakan pada konteks tuturan pembicara dan kawan bicara berada dalam konteks situasi yang akrab, dan saya digunakan pada konteks situasi yang formal. Satuan $k u$ - bentuk terikat lekat kiri tidak ditemukan dalam data penelitian ini. 
Tabel 2

Analisis Deiksis Persona Pertama dengan Persona Kedua

\begin{tabular}{|l|l|l|l|l|l|}
\hline No & Lokasi terjadinya tuturan & Wujud Imperatif & Konteks tuturan & Makna imperatif & $\begin{array}{l}\text { Deikis } \\
\text { persona }\end{array}$ \\
\hline h.31 & Di jalan menuju rumah sakit & $\begin{array}{l}\text { "Kenapa Ausyah } \\
\text { tidak kita beri } \\
\text { kesempatan"? }\end{array}$ & $\begin{array}{l}\text { Ausyah dituduh } \\
\text { berbuat zina oleh } \\
\text { masyarakat sekitar } \\
\text { tempat tinggalnya }\end{array}$ & Pertanyaan & 'kita' \\
\hline h.20 & Di rumah di ruang tidur & $\begin{array}{l}\text { "Kalau begini, } \\
\text { berarti bahtera } \\
\text { hidup kita selama } \\
\text { ini hanya } \\
\text { merupakan suatu } \\
\text { kebohongan" }\end{array}$ & $\begin{array}{l}\text { Salim marah kepada } \\
\text { istrinya }\end{array}$ & Dugaan & 'kita' \\
\hline
\end{tabular}

Tabel 3

Analisis Deiksis Persona Pertama dengan Tanpa Persona Kedua

\begin{tabular}{|l|l|l|l|l|l|}
\hline No & Lokasi terjadinya tuturan & Wujud Imperatif & Konteks tuturan & Makna imperatif & $\begin{array}{l}\text { Deikis } \\
\text { persona }\end{array}$ \\
\hline 1 & Di tengah laut di atas kapal & $\begin{array}{l}\text { "Kami saling } \\
\text { berantukkan dan } \\
\text { berteriak" }\end{array}$ & $\begin{array}{l}\text { Saat kapal yang } \\
\text { dinaiki penumpan } \\
\text { goleh ditiup angin }\end{array}$ & Penyataan \\
\hline 2 & Di tengah laut di atas kapal & $\begin{array}{l}\text { "Kepala kami } \\
\text { saling beradu dan } \\
\text { kami } \\
\text { bergantungan } \\
\text { kemana saja" }\end{array}$ & $\begin{array}{l}\text { Saat kapal yang } \\
\text { dinaiki penumpan } \\
\text { goleh ditiup angin }\end{array}$ & Pernyataan \\
\hline H 30 & Di rumah direktur Hasan & $\begin{array}{l}\text { "Kami heran } \\
\text { dengan } \\
\text { pendekatan } \\
\text { Hasan tersebut" }\end{array}$ & $\begin{array}{l}\text { Teman-teman Hasan } \\
\text { heran melhat Hasan } \\
\text { yang sangat dekat } \\
\text { dengan direkturnya }\end{array}$ & Pernyataan \\
\hline
\end{tabular}

Tabel 4

Analisis Deiksis Persona Kedua

\begin{tabular}{|l|l|l|l|l|l|}
\hline No & Lokasi terjadinya tuturan & Wujud Imperatif & Konteks tuturan & $\begin{array}{l}\text { Makna } \\
\text { imperatif }\end{array}$ & $\begin{array}{l}\text { Deikis } \\
\text { persona }\end{array}$ \\
\hline 1 & $\begin{array}{l}\text { Di ruang tidur di dalam } \\
\text { rumah }\end{array}$ & $\begin{array}{l}\text { "Kenapa tidak? } \\
\text { Bukankah kau yang } \\
\text { melahirkan? dan }\end{array}$ & $\begin{array}{l}\text { Sebelum penjelasan dari } \\
\text { dokter kandungan bahwa } \\
\text { Salim mandul }\end{array}$ & Pertanyaan & 'kau' \\
\hline 2 & Di ruang praktek dokter & $\begin{array}{l}\text { "Kau perempuan } \\
\text { berhati tulus" }\end{array}$ & $\begin{array}{l}\text { Dokter menjelaskan tak } \\
\text { perlu cemburu pada suami }\end{array}$ & Pernyataan & 'kau' \\
\hline
\end{tabular}




\begin{tabular}{|l|l|l|l|l|l|}
\hline 3 & Di ruang praktek dokter & $\begin{array}{l}\text { "Saya pastikan } \\
\text { Anda sehat dan } \\
\text { tidak mandul. }\end{array}$ & $\begin{array}{l}\text { Dokter menjelaskan hasil } \\
\text { pemeriksaan laboratorium } \\
\text { Laila }\end{array}$ & Pernyataan & 'Anda' \\
\hline 4 & Di ruang praktek dokter & $\begin{array}{l}\text { "Tapi Anda sudah } \\
\text { meemriksanya, } \\
\text { Dok" }\end{array}$ & $\begin{array}{l}\text { Laila menegaskan hasil } \\
\text { pemeriksaan kandungan }\end{array}$ & Penegasan & 'Anda' \\
\hline 5 & Di ruang rapat di kantor & "Apa maksudmu?" & $\begin{array}{l}\text { Direktur bertanya harga } \\
\text { minyak yang tak tetap }\end{array}$ & Pertanyaan & '-mu' \\
\hline 6 & Di ruang rapat di kantor & $\begin{array}{l}\text { "Kau merobah pola } \\
\text { pikiranmu" pola }\end{array}$ & $\begin{array}{l}\text { Direktur } \\
\text { penjelasan kesalahan yang } \\
\text { dilakukan Fuad }\end{array}$ & Imbauan & '-mu' \\
\hline
\end{tabular}

Analisis data seperti tertera pada tabel 4 menunjukkan bahwa, penggunaan deiksis persona kedua pada umumnya menggunakan kau, Anda, dan -mu bentuk terikat lekat kanan. Kau, dan -mu digunakan pada konteks tuturan pembicara dan kawan bicara berada dalam konteks situasi yang akrab, dan Anda digunakan pada konteks situasi yang formal. Satuan kamu bentuk bebas tidak ditemukan dalam data penelitian ini.

\section{Tabel 5}

Analisis Deiksis Persona Kedua Lebih Dari Satu

\begin{tabular}{|c|c|c|c|c|c|}
\hline No & Lokasi terjadinya tuturan & Wujud Imperatif & Konteks tuturan & Makna imperatif & Deikis persona \\
\hline 1 & Di pasar, di toko minuman & $\begin{array}{l}\text { "Apa } \quad \text { kamu } \\
\text { sekalian belum } \\
\text { mendengar tentang } \\
\text { orang sholeh yang } \\
\text { berbuat } \\
\text { kontradiktif?" }\end{array}$ & $\begin{array}{l}\text { Pedagang yang } \\
\text { berkata sinis dengan } \\
\text { orang-orang di pasar } \\
\text { yang dekat dengan } \\
\text { tempat jualannya }\end{array}$ & pertanyaan & 'kamu' \\
\hline h. 138 & $\begin{array}{l}\text { Di dalam kapal di atas air } \\
\text { laut }\end{array}$ & $\begin{array}{l}\text { "Para penumpang! } \\
\text { Kalian tetap di } \\
\text { tempat, siapa yang } \\
\text { bergerak saya akan } \\
\text { lemparkan } \quad k e \\
\text { tengah laut". }\end{array}$ & $\begin{array}{l}\text { Kapal laut mengalami } \\
\text { kerusakan sehingga } \\
\text { kapal akan tenggelam }\end{array}$ & imabauan & 'kalian' \\
\hline h. 40 & Di pasar ikan & $\begin{array}{l}\text { "Dia sudah } \\
\text { menceritakan } \\
\text { hubungan kalian } \\
\text { kepada ayahnya" }\end{array}$ & $\begin{array}{l}\text { Ruqayah berbisik } \\
\text { kepada suaminya di } \\
\text { dalam kamar tidur } \\
\text { tanpa merasa ada } \\
\text { yang mendengarkan } \\
\text { pembicaraan mereka } \\
\text { di luar kamar }\end{array}$ & pemberitahuan & 'kalian' \\
\hline
\end{tabular}

Analisis data seperti tertera pada tabel 5 menunjukkan bahwa, penggunaan deiksis persona kedua lebih dari satu kamu, kalian tidak banyak digunakan pada konteks tuturan pembicara dan kawan bicara, baik berada dalam konteks situasi yang akrab maupun konteks situasi yang formal. 


\begin{tabular}{|c|c|c|c|c|c|}
\hline No & Lokasi terjadinya tuturan & Wujud Imperatif & Konteks tuturan & Makna imperatif & Deikis persona \\
\hline h. 51 & Di kafe & $\begin{array}{l}\text { Perempuan- } \\
\text { perempuan itu } \\
\text { tertawa, sesorang } \\
\text { di antara mereka } \\
\text { berkata kepadaku: } \\
\text { Apa yang kau } \\
\text { takutkan saudaraku }\end{array}$ & $\begin{array}{l}\text { Setelah simuman dari } \\
\text { mabuk }\end{array}$ & pertanyaan & 'mereka' \\
\hline h. 40 & Di kantor & $\begin{array}{lr}\text { "Mereka sebarkan } \\
\text { isu } & \text { bahwa } \\
\text { pergaulan ayah } \\
\text { Sultan itu buruk } \\
\text { dan keji" }\end{array}$ & $\begin{array}{l}\text { Perbuatan iri yang } \\
\text { dilakukan } \\
\text { Sultan di kantor }\end{array}$ & pernyataan & 'mereka' \\
\hline h. 152 & Di masjid & $\begin{array}{l}\text { "di antara } \text { mereka } \\
\text { ada } \\
\text { Muthalib" }\end{array}$ & 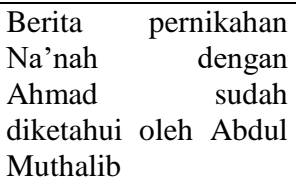 & pemberitahuan & 'mereka' \\
\hline
\end{tabular}

Analisis data seperti tertera pada tabel 6 menunjukkan bahwa, penggunaan deiksis persona ketiga mereka banyak digunakan pada konteks tuturan pembicara dan kawan bicara, baik berada dalam konteks situasi yang akrab maupun konteks situasi yang formal.

\section{Tabel 7}

Analisis Deiksis Ruang

\begin{tabular}{|c|c|c|c|c|c|}
\hline No & Lokasi terjadinya tuturan & Wujud Imperatif & Konteks tuturan & Makna imperatif & Deikis ruang \\
\hline h.51 & Di rumah Na'nah & $\begin{array}{l}\text { "Berita itu } \\
\text { mengundang } \\
\text { komentar-komentar } \\
\text { yang bersifat } \\
\text { mengecam" }\end{array}$ & \begin{tabular}{lr} 
Berita & pernikahan \\
Na'nah dan Ahmad \\
yang mengejutkan \\
\multicolumn{2}{l}{ Abdul Muthalib }
\end{tabular} & pernyataan & 'itu’ \\
\hline h. 32 & Di ruang kerja & $\begin{array}{l}\text { "Mengapa tidak dari } \\
\text { dulu kau datang ke } \\
\text { sini?" }\end{array}$ & $\begin{array}{l}\text { Hasan sudah lama } \\
\text { tidak pernah datang } \\
\text { ke ruang kerja Haki } \\
\text { Adnan }\end{array}$ & pertanyaan & 'ke sini' \\
\hline h. 32 & Di pasar & $\begin{array}{lr}\text { "Hidup ini } & \text { kejam, } \\
\text { Oh.., aku lihat di sini } \\
\text { bermaam-macam } \\
\text { jenis } \quad \text { manusia, } \\
\text { bermacam-macam } \\
\text { ider } \quad \text { bermacam- } \\
\text { macam r jenis } \\
\text { manusia. }\end{array}$ & $\begin{array}{l}\text { Hasan mengetahui } \\
\text { keadaan nasi }\end{array}$ & pernyataan & 'di sini' \\
\hline h. 2 & $\begin{array}{llr}\text { Masyarakat } & & \text { yang } \\
\text { mempunyai } & \text { pemimpin } \\
\text { yang zalim, di suatu } \\
\text { tempat }\end{array}$ & $\begin{array}{l}\text { "Kini rasa haus dan } \\
\text { dahagar seakan } \\
\text { membunuhnya". }\end{array}$ & $\begin{array}{l}\text { Seorang yang tidak } \\
\text { memiliki pekerjaan } \\
\text { yang tidak dapat } \\
\text { membli sesuatu }\end{array}$ & pernyataan & 'kini \\
\hline
\end{tabular}


Analisis data seperti tertera pada tabel 7 menunjukkan bahwa, penggunaan deiksis demonstratif 'itu', lokatif, 'di sini, di situ, ke sana' dan temporal 'kini' banyak digunakan pada konteks tuturan pembicara dan kawan bicara, baik berada dalam konteks situasi yang akrab maupun konteks situasi yang formal.

\section{Tabel 8}

\section{Analisis Deiksis Waktu}

\begin{tabular}{|c|c|c|c|c|c|}
\hline No & Lokasi terjadinya tuturan & Wujud Imperatif & Konteks tuturan & Makna imperatif & Deikis waktu \\
\hline h. 164 & Di rumah & $\begin{array}{l}\text { "Dulu, memang dia } \\
\text { pernah mendengar } \\
\text { nama kelompok } \\
\text { itu" }\end{array}$ & $\begin{array}{l}\text { Membahasa } \\
\text { keberadaan kelompok } \\
\text { Al-Ikhwan }\end{array}$ & pernyataan & 'dulu \\
\hline h. 140 & Di desa & $\begin{array}{ll}\text { "Hari-hari } & \text { yang } \\
\text { mencekam } & \text { terus } \\
\text { berlalu" } & \end{array}$ & $\begin{array}{l}\text { Peristiwa serangan } \\
\text { dari kelompok Al- } \\
\text { Ikhwan terhadap } \\
\text { penduduk desa }\end{array}$ & pernyataan & 'hari-hari' \\
\hline h. 165 & Di desa & $\begin{array}{l}\text { "Peristiwa } \quad \text { itu } \\
\text { terjadi pada tahun } \\
1965 "\end{array}$ & $\begin{array}{l}\text { Peristiwa serangan } \\
\text { dari kelompok Al- } \\
\text { Ikhwan terhadap } \\
\text { penduduk desa }\end{array}$ & pernyataan & 'tahun 1965' \\
\hline h. 34 & Di rumah tokoh Hasan & $\begin{array}{l}\text { 'Di suatu pagi pada } \\
\text { musim panas yang } \\
\text { ceria' }\end{array}$ & $\begin{array}{lr}\text { Setelah } & \text { bangun dari } \\
\text { tidurnya } & \text { Hasan } \\
\text { merasakan } & \text { situasi } \\
\text { pagi } & \end{array}$ & pernyataan & 'pagi \\
\hline
\end{tabular}

Analisis data seperti tertera pada tabel 8 menunjukkan bahwa, penggunaan deiksis waktu dulu, hari-hari, tahun 1965 banyak digunakan pada konteks tuturan pembicara dan kawan bicara, baik berada dalam konteks situasi yang akrab maupun konteks situasi yang formal.

Tabel 9

Analisis Deiksis Wacana

\begin{tabular}{|c|c|c|c|c|c|}
\hline No & Lokasi terjadinya tuturan & Wujud Imperatif & Konteks tuturan & $\begin{array}{l}\text { Makna } \\
\text { imperatif }\end{array}$ & Deikis wacana \\
\hline h. 4 & Di suatu tempat & $\begin{array}{l}\text { "Ucapan } \quad \text { itu } \\
\text { laksana petir yang } \\
\text { menyambar } \\
\text { telinganya. } \\
\text { Ditatapnya }\end{array}$ & $\begin{array}{l}\text { Ketika seorang } \\
\text { pemimpin turun dari } \\
\text { jabatannya, seolah-olah } \\
\text { berkata padanya: Hai } \\
\text { pembohong! }\end{array}$ & pernyataan & $\begin{array}{l}\text { 'ucapan } \\
\text { laksana petir' }\end{array}$ \\
\hline h. 140 & Di bekas ruang kerja & $\begin{array}{l}\text { "Sekarang dia } \\
\text { berani } \\
\text { membesarkan } \\
\text { batang hidungnya } \\
\text { alias congkak" }\end{array}$ & $\begin{array}{l}\text { Sang mantan penguasa } \\
\text { menatap meja antic } \\
\text { yang pernah menjadi } \\
\text { ruang kerjanya }\end{array}$ & pernyataan & 'congkak' \\
\hline h. 11 & Ruang khayalan/halusinasi & $\begin{array}{l}\text { "Lapangan } \\
\text { penghisapan ini } \\
\text { sudah dipadati oleh } \\
\text { makhluk yang } \\
\text { sedang kehausan. } \\
\text { Lidah-lidah }\end{array}$ & $\begin{array}{ll}\text { Halusinasi } & \text { yang } \\
\text { menggambarka } & \text { alam } \\
\text { akhirat } & \end{array}$ & pernyataan & $\begin{array}{l}\text { 'lidah mereka } \\
\text { laksana bunga } \\
\text { api' }\end{array}$ \\
\hline
\end{tabular}




\begin{tabular}{|l|l|l|l|l|l|}
\hline & & $\begin{array}{l}\text { mnereka semakin } \\
\text { panjang menjulur } \\
\text { laksana bunga api }\end{array}$ & & & \\
\hline h.34 & $\begin{array}{l}\text { Di rumah tokoh Salim, } \\
\text { istri sedang membujuknya }\end{array}$ & $\begin{array}{l}\text { "Ketika padang } \\
\text { pasir menghijau ya } \\
\text { Salim, aku merasa } \\
\text { benar-benar hidup, } \\
\text { harapan yang dalam keadaan } \\
\text { indah bernyanyi di } \\
\text { kalbuku } \\
\text { kegembriaan dan } \\
\text { mengusir air } \\
\text { mataku" }\end{array}$ & $\begin{array}{l}\text { Salim } \\
\text { melamun } \\
\text { mataku' }\end{array}$ \\
\hline
\end{tabular}

Analisis data seperti tertera pada tabel 9 menunjukkan bahwa, penggunaan deiksis wacana yakni penggunaan bahasa dalam kaitan dengan penggunaan ungkapan dalam ujaran seperti Matahari dengan ronanya yang pucat semakin condong ke barat, Fudah adalah orang yang tak pantas dihargai. Ibarat anjing yang menggigit tangan orang yang telah menolongnya, direktur tak mampu mengunci bibirnya banyak digunakan pada konteks tuturan pembicara dan kawan bicara, baik berada dalam konteks situasi yang akrab maupun konteks situasi yang formal.

Tabel 10

Analisis Deiksis Sosial

\begin{tabular}{|c|c|c|c|c|c|}
\hline No & Lokasi terjadinya tuturan & Wujud Imperatif & Konteks tuturan & $\begin{array}{l}\text { Makna } \\
\text { imperatif }\end{array}$ & Deikis sosial \\
\hline h. 149 & Di rumah Na'nah & $\begin{array}{l}\text { "Selamat datang } \\
\text { kekasih!" }\end{array}$ & \begin{tabular}{lr} 
Seorang & \multicolumn{2}{l}{ pemuda } \\
menghempaskan pintu \\
dengan marah lalu \\
mendekatkan Na'nah \\
dengan & kepalan \\
tinjunya. & Na'nah \\
langsung berkata...
\end{tabular} & pernyataan & 'etika bahasa' \\
\hline h. 150 & Di rumah Na'nah & "Hei wanita laknat & $\begin{array}{l}\text { Pemuda beranama } \\
\text { Ahmad tu meemgang } \\
\text { tangan Na'nah sambil } \\
\text { menghardik... }\end{array}$ & hardikan & 'etika sosial' \\
\hline h. 150 & Di rumah Na'nah & $\begin{array}{l}\text { "Kekasihmu wanita } \\
\text { laknat?" }\end{array}$ & $\begin{array}{l}\text { Dituduh sebagai wanita } \\
\text { laknat Na'nah } \\
\text { menjawab histeris } \\
\text { tanpa rasa takut }\end{array}$ & pertanyaan & 'etika sosial' \\
\hline h. 150 & Di rumah Na'nah & $\begin{array}{l}\text { "Hentikan tipu } \\
\text { dayamu" }\end{array}$ & $\begin{array}{l}\text { Bersikukuh menuduh } \\
\text { Na'nah melakukan tipu } \\
\text { daya terhadap dirinya }\end{array}$ & pernyataan & 'etika sosial' \\
\hline h. 150 & Di rumah Na'nah & "Apa yang tejadi?" & $\begin{array}{l}\text { Dituduh sebagai wanita } \\
\text { laknat Na'nah } \\
\text { menjawab histeris } \\
\text { tanpa rasa takut }\end{array}$ & pertanyaan & 'etika bahasa' \\
\hline h. 150 & Di rumah Na'nah & "Istirahat dulu kau & $\begin{array}{l}\text { Dituduh sebagai wanita } \\
\text { laknat } \quad \text { Na'nah }\end{array}$ & permohonan & 'etika sosial' \\
\hline
\end{tabular}




\begin{tabular}{|l|l|l|l|l|l|}
\hline & sedang stress?” & $\begin{array}{l}\text { menjawab histeris } \\
\text { tanpa rasa takut }\end{array}$ & & \\
\hline
\end{tabular}

Analisis data seperti tertera pada tabel 10 menunjukkan bahwa, penggunaan deiksis sosial yakni penggunaan bahasa dalam kaitan dengan penggunaan ungkapan dalam ujaran seperti etika sosial dan etika bahasa yang banyak digunakan pada konteks tuturan pembicara dan kawan bicara, baik berada dalam konteks situasi yang akrab maupun konteks situasi yang formal.

\section{2) Pembahasan}

Uaraian pembahasan ini dimaksudkan untuk mengungkapka kembali temuan-temuan hasil analisis data penelitia, dilihat dari segi teori-teori yang menjadi landasannya dan hasil hasil penelietian yang relevan sebelumnya. Pembahasan ini dipaparkan menurut urutan permasalahan dan tujuan yang diajukan pada bagian pendahuluan, dan uraian pembahasan ini pada akhirnya memperlihatkan deiksis yang digunakan dalam kumpulan cerpen ini.

Di dalam kumpulan cerpen karya Najib Kailani yang berjudul Al-Kabuus yang diterjemahkan ke dalam bahasa Indonesia menjadi "Halusinasi" oleh Zuriyati. Di dalam karya itu banyak digunakan deiksis persona $a k u$, saya dan -ku bentuk terikat lekat kanan. Sedangkan bentuk daku dan $k u$ - bentuk terikat lekat kiri tidak digunakan di dalam karya terjemahan ini.

\section{(1) Deiksis persona pertama}

Deiksis persona pertama yang dominan digunakan dalam karya ini adalah saya, aku dan -ku. Chaer (2010) mengemukakan bahwa kata ganti atau deiksis saya untuk menggantikan diri si pembicara dapat digunakan oleh siapa saja terhadap siapa saja. Dalam pertuturan yang bersifat akrab, misalnya dalam keluarga, biasa digunakan katakata nama diri. Dalam penggunaannya dijelaskan bahwa kata ganti saya digunakan kepada orang yang lebih tua, orang yang belum dikenal, orang yang dihormati dan salam situasi resmi. ${ }^{22}$ Karya terjemahan ini menggunakan kata ganti persona pertama, sesuai situasi seperti tersebut di atas. Sedangkan, kata ganti $a k u$ dipakai untuk menggantikan diri pembicara dapat digunakan kepada teman akrab yang sudah akrab, orang yang lebih muda, orang yang lebih rendah status atau kedudukan sosialnya dan dalam situasi-situasi tertentu sedang marah, atau jengkel. Contoh: "Oh hari ini aku sungguh bahagia. Aku memberimu hadiah." ... data (hal 39). Di sisi lain, kata ganti -ku dignakan dalam kalimat dengan kata kerja pasif, sebagai objek dalam kalimat berkata kerja transitif, dalam kontruksi yang menyatakan kepunyaan. Contoh: "Adapun saudaraku Husein berdiri dengan kepala tertunduk malu, sambil berkata: Dari mana isu selama ini”? .. data (hal 47).

\section{(2) Deiksis Persona Kedua}

Deiksis persona kamu, Anda, kau dan -mu merupakan deiksis yang dominan digunakan dalam karya ini. Chaer (2010) mengemukakan bahwa kata ganti atau deiksis Anda untuk menyatakan diri kedua, atau orang yang diajak bicara, dapat digunakian kepada orang yang belum dikenal dan diperkirakan berusia sebaya, atau dalam situasi resmi. ${ }^{23}$ Contoh: "Saya pastikan Anda sehat dan tidak mandul. Tinggal

\footnotetext{
22 Abdul Chaer. Tata Bahasa Praktis Bahasa Indonesia (Jakarta: Rineka Cipta, 2010)., hal 92.

${ }^{23}$ Ibid., Abdul Chaer., hal 96
} 
pemeriksaan suami Anda.” ... data (hal 75).

Di sisi lain, kata ganti atau deiksis kau utnuk menyatakan diri orang kedua, atau orang yang diajak bicara dapat digunakan kepada orang yang sudah akrab, orang yang lebih muda, orang yang lebih rendah status atau kedudukan sosialnya atau dalam situasisituasi tertentu misalnya sedang marah atau jengkel. Deikis kau digunakan untuk hubungan kekerabatan. Kau digunakan dalam kalimat berkata kerja pasif dan dalam kontruksi yang menyatkan kepunyaan atau pemilihan. Contoh: "Kau jual”? protes Muhamad .. data (hal 106). "Kau menjual ide"? ... data (hal 107). "Apa kau tidak makan malam?" ... (data hal 107).

\section{(3) Deiksis Persona Ketiga}

Deiksis persona ketiga mereka merupakan deiksis yang dominan digunakan dalam karya ini. Chaer (2010) mengemukakan bahwa kata ganti atau deiksis mereka untuk menyatakan diri orang ketiga, atau orang yang dibicarakan, yang jumlahnya lebih dari seorang. Dapat digunakan terhadap siapa saja dan oleh siapa saja. ${ }^{24}$ Contoh: "Tatkala mereka yakin bahwa usaha mereka sia-sia mereka menyelimutinya dengan sehelai kain woll lalu mereka dudukkan di atas kudanya yang pincang. " ... data (hal 80).

"Hari demi hari pun berlalu sementara mereka tidak bisa menabung satu qursy pun"? data (hal 86). "Mereka tertawatawa dan berlari-lari di dalam rumah sambil berteriak"? ... data (hal 86).

\section{(4) Deiksis Tempat}

Deiksis tempat merupakan deiksis yang dominan digunakan dalam karya ini. Nadar (2009) mengemukakan

${ }^{24}$ Ibid., Abdul Chaer., hal 96 bahwa deiksis tempat atau ruang untuk menyatakan lokatif, yaitu sini, situ, sana, di sini, di situ, di sana. ${ }^{25}$ Contoh: "Inilah drama Shaira karya Muhammad Bakri. Produser Fulan selamat mendengarkan." ... data (hal 111).

"Aku juga mau ke sana”. Ayo ikut aku? data (hal 110). "Kau kenal dengan orang-orang dibagian produksi itu"? ... data (hal 110).

\section{(5) Deiksis Wacana}

Deiksis wacana merujuk penggunaan bahasa dalam bentuk ungkapan. Ungkapan yang digunakan dalam karya ini berupa beraneka gaya bahasa kiasan. Ungkapan dalam hal ini pemakaian gaya bahasa kiasan. Satuan bahasa itu merupakan deiksis yang dominan digunakan dalam karya ini. Keraf (1981) mengemukakan bahwa gaya bahasa kiasan adalah gaya yang dilihat dari segi makna tidak dapat ditafsirkan sesuai dengan makna katakata yang membentuknya. Orang harus mencari makna di luar rangkaian kata atau kalimatnya. Jenis gaya bahasa ini disebut juga dengan trope. ${ }^{26}$ Lebih lanjut, Keraf (1981) menjelaskan bahwa trope menurut arti katanya adalah 'penyimpangan' makna dari kata atau kalimat-kalimat.

Gaya bahasa ini menurut Keraf (1981) merupakan gaya kiasan yang dibentuk berdasarkan persamaan atau perbandingan. Membandingkan sesuatu dengan sesuatu hal yang lain berarti mencoba menemukan ciri-ciri yang menunjukkan kesamaan antra kedua hal tersebut. ${ }^{27}$ Contoh: "Nama Fuad menjadi harum.” ... data (hal 118).

\footnotetext{
25 F.X. Nadar. Pragmatik dan Penelitian Pragmatik (Yogyakarta: Graha Ilmu, 2009)., hal 59.

${ }^{26}$ Gorys Keraf. Diksi dan Gaya Bahasa (Ende: Nusa Indah, 1981)., hal 121.

${ }^{27}$ Ibid.
} 
"Akan tetapi sekertaris pribadinya itulah yang senantiasa menghembushembuskan berita buruk sehingga dia mengambilkan keputusan yang pahit untuk Fuad"? data (hal 118). "Seiring denga itu, suara azan sayup-sayup berkumandeang memanggil manusia untuk shalat fajar, Abdul Jabbar mengulurkan tangannya sambil berakta " Aku berjanji padamu”? ... data (hal 160).

\section{(6) Deiksis Sosial}

Deiksis sosial berkaitan dengan tiga aspek partisipan yaitu, penyapa, pesapa, acuan, demikian deikis sosial ini tercakupi unsur honorifik atau sebutan penghormatan dan etika bahasa. Levinson (1983) mengemukakan bahwa penggunaan ekspresi deiksis ini ada dua jenis, yaitu dilihat melalui : 1) gestrual, yaitu penggunaan ekspresi deiksis yang memerlukan informasi gerak fisikal dalam suatu konteks ujaran. ${ }^{28}$ Contoh: "Direktur itu menggelengkan kepalanya keheranan lalu melanjutkan pekerjaannya seperti menandatangani surat-surat yang sudah menumpuk di mejanya dan membuat catatan penting." ... data (hal 117).

"Dengan penuh doa dari lubuk hatinya, sambil menengadahkan ke langit: Ooh Tuhan demi Rajak, Ibrahim dan istriku yang malang"? data (hal 116).

Deiksis gestural adalah kegiatan yang dilakukan oleh para tokoh pada saat berlangsungnya sebua peristiwa

\section{(7) Deiksis Pemakaian Deiksis dalam Kalimat Imperatif}

Deiksis persona ketiga mereka merupakan deiksis yang dominan digunakan dalam karya ini. Chaer (2010) mengemukakan bahwa kata ganti atau deiksis mereka untuk menyatakan diri orang ketiga, atau orang yang dibicarakan, yang jumlahnya lebih dari seorang. Dapat digunakan terhadap siapa saja dan oleh siapa saja. ${ }^{29}$ Contoh: "Tatkala mereka yakin bahwa usaha mereka sia-sia mereka menyelimutinya dengan sehelai kain woll lalu mereka dudukkan di atas kudanya yang pincang." ... data (hal 80).

" Hari demi hari pun berlalu sementara mereka tidak bisa menabung satu qursy pun"? data (hal 86). Kalimat ini merupakan kalimat imperatif literal dengan modus kalimat beritra yang digunakan saat suasana santai dan tidak ada perasaan kesal atau marah.

\section{Simpulan}

Uraian di atas dapat disimpulkan sebagai berikut:

1. Jenis satuan bahswa pengungkap waktu dapat berupa satuan lingual ruang dan satuan lingual waktu

2. Penentuan pengelompokkan konsep waktu yang digunakan penerjemah secara deiktis merujuk kepadea satuan lingual itu didasarkan kepada titik peristiwa dengan masing-masing konteks yang melingkupinya.

3. Berkenaan dengan acuan waktu dari satuan lingual waktu ditemukan beberapa konsep waktu yang mengarah: a) maju, b) mundur, c) durasi, d) waktu bersamaan dan e) jangka waktu.

4. Untuk mengungkap deiksis waktu digunakan bentuk bahasa yang memposisikan waktu terjadinya peristiwa, keadaan yang tercermin di dalam sebuah tuturan atau kalimat penggambar peristiwa itu.

\footnotetext{
${ }^{29}$ Ibid., Abdul Chaer., hal 96
}

${ }^{28}$ Op.cit., Levinson., hal 96 


\section{DAFTAR PUSTAKA}

Badudu, J.S. 2000. dalam I Dewa Putu Wujaya dan Muhammad Rohmadi. Analisis Wacana Pragmatik Kajian Teori dan Analisis. 2011. Surakarta: Yuma Pustaka

Chaer, Abdul. 2010. Tata Bahasa

Praktis Bahasa Indonesia. Jakarta:

Rineka Cipta

Fillmore, Charles, J. 1971. Santa Cruz Lectures on Deixis 1971. Bloomington: Indiana University Linguistics Club

F.X. Nadar, F.X. 2009. Pragmatik dan Penelitian Pragmatik. Yogyakarta:

Graha Ilmu

Keraf, Gorys. Diksi dan Gaya Bahasa. Ende: Nusa Indah.

Kaswanti Purwo, Bambang. 1990. Pragmatik dan Pengajaran Bahasa Menyibak Kurikulum 1984. Yogyakarta: Kanisius

Lyons, John. 1977. Semantics.

Cambridge: Cambridge University Press Steven C. Levinson. 1983. Pragmatics. Cambridge: Cambridge Univeersity Press. 
Darsita : "Deiksis” dalam ... 365 